\title{
Influence of Professional Commitment and Organizational Climate on the Work Engagement of Employees in the Department of Education
}

\author{
Ofelia P. Sanchez \\ Faculty of the Professional Schools \\ University of Mindanao \\ Davao City
}

\begin{abstract}
The main purpose of this study was to determine whether work engagement mediates the relationship between professional commitment and organizational climate. The study employed a quantitative, nonexperimental design using a correlational technique. The respondents were the public school non-teaching personnel of the Davao de Oro Division. Mean, Pearson-r, and Regression Analysis were used to determine the study's findings. Moreover, adapted survey questionnaires were used for professional commitment, organizational climate, and work engagement. Results revealed that the level of professional commitment is very high, the level of organizational climate is very high, and the level of work engagement among non-teaching personnel is very high. Further, there were significant relationships between professional commitment and work engagement and between organizational climate and work engagement. In its singular capacity, among professional commitment and organizational climate, organizational climate best influences the work engagement having the highest beta coefficient. However, professional commitment can also influence the working competence but with the support of other variables.
\end{abstract}

Keywords: professional commitment, organizational climate, work engagement, regression analysis, Davao de Oro Division, Philippines

\section{Introduction}

\section{Rationale}

The influence of professional commitment affects work performance. In the same way, organizational climate is the force that keeps every member of the organization engaged. Poor work engagement causes dissatisfaction, disruption, and low performance among employees. Those who do not show active engagement towards their job and are hesitant to cooperate with others bring organizational performance drops to a low level (Febriansyah, Pringgabayu, Hidayanti, \& Febrianti, 2018). It was identified that disengagement is central to the problem of workers' lack of commitment and satisfaction towards their job (Schaufeli \& Bakker, 2015). A study on work engagement schools revealed that burnout among employees is being experienced, manifested by emotional exhaustion, desensitization, and personal underachievement (Kose, 2016).

The significance of work engagement is that it can result in beneficial outcomes for the organization. Work engagement research indicates that a high level of engagement results in an increased sense of organizational responsibility, increased job satisfaction, decreased absenteeism and workload ratios, better healthcare and well-being, a display of more organizational ethics, high performance, increased demands on personal efforts, preventive behaviors, and motivation to learn (Schaufeli \& Salanova, 2017). Engaging employees can be critical to competitiveness (Macey \& Schneider, 2015) and organizational success (Macey \& Schneider, 2015). (Lockwood, 2017).

Accordingly, it was found out that professional commitment and organizational climate are associated with work engagement (Kose, 2016; Febriansyah, Pringgabayu, Hidayanti, Febrianti, 2018; \& Haugsnes, 2016). 
They pointed out that professional commitment is the role obligation of employee measurable behavior pattern according to certain rules, norms and code of ethics of the employee profession make its organizational climate. These two powerful factors can lead to employees work engagement. According to Bakker's (2009) idea of work engagement, an engaged employee has a very positive attitude, is characterized by inexhaustible vigor and energy, and possesses the will and motivation to work and invest the effort necessary to sustain a favorable climate.

Meanwhile, studies on work engagement were correlated with different factors such as organizational commitment, self-efficacy, organizational growth, organizational climate, work performance, and job satisfaction. These factors were known to significantly affect employee engagement (Albrecht, 2015; Bakker \& Albrecht, 2018; Lisbona, 2018). However, those existing studies correlating the abovementioned variables were done in foreign settings. The researcher has not come across a study on the influence of professional commitment and organizational climate on work engagement in the local setting. In this context, the researcher is interested in determining whether professional commitment and organizational climate influence employees' work engagement as this can lead to long-term employee retention, higher levels of productivity, and improved quality of work.

\section{Research Objectives}

This study aimed to determine whether professional commitment and organizational climate significantly influence employees' work engagement. Specifically, this will try to achieve the following objectives to wit:

1. To ascertain the level of professional commitment among DepEd employees in terms of:

1.1 affective professional commitment;

1.2 continuance professional commitment; and

1.3 normative professional commitment.

2. To assess the level of organizational climate of the DepEd employees in terms of:

2.1 mechanism;

2.2 trust, team spirit, and objectivity;

2.3 autonomy, openness, and interpersonal relationship;

2.4 management beliefs and commitment; and

2.5 training, development, and management support and encouragement.

3. To ascertain the level of work engagement among DepEd employees in terms of:

3.1 cognitive work engagement;

3.2 emotional work engagement; and

3.3 physical work engagement.

4 To determine the relationship between professional commitment and organizational climate and work engagement.

5. To identify which of the exogenous variables best influences work engagement.

\section{Hypothesis}

The following null hypotheses were tested at 0.05 levels of significance.

1. There is no significant relationship between:

1.1 professional commitment and work engagement, and

1.2 organizational climate and work engagement.

2. There is no significant influence between professional commitment, organizational climate, and work engagement, both individual and aggregate capacity.

\section{Review of Related Literature and Studies}

Various ideas, points of view, theories, findings from research and publications, and valuable insights from different authors relevant to related topics of the study are presented in this section that provides substantive proof to clearly support the research objectives essential for the manifestation of understanding in the study. The independent variables are professional commitment, as measured by affective, continuing, and normative indicators (Bagraim, 2003); organizational climate, as measured by mechanisms; trust, team spirit, and objectivity; autonomy, openness, and interpersonal relationships; management beliefs and 
commitment; and training, development, and governance support and encouragement. (2018) (Chaudhary, Rangnekar, and Barua). The dependent variable is work engagement, measured using indicators such as cognitive, emotional, and physical job involvement (Kuok \& Taomina, 2017).

\section{Professional Commitment}

Professional commitment refers to the measure of the strength of the employees' identification with the goals and values of their profession, having strong faith in it, and showing considerable effort to continue in the membership of the profession. Employees' professional commitment refers to the willingness of the employee to go the extra mile to ensure that clients can be satisfied. Professionally committed employees assist clients in their extra time, cooperate with and are willing to work with clients, and utilize work time profitably (Nazari \& Emami, 2017).

Meanwhile, commitment plays an important role in determining whether they remain in the profession. Thus, it may be possible to determine which employees are at risk of leaving by examining their professional commitment. It impacts people's working behaviors, such as their observable attitudes, judgments about the working end, and involvement in professional groups (Fresko, Kfir, \& Nasser, 2016).

Professional commitment is associated with beneficial behaviors for the organization. Individuals who exhibit a high level of professional commitment engage in fewer actions detrimental to the business ( Nazari \& Emami, 2017). It is a multifaceted structure. It refers to an individual's socio-psychological attachment to a group or organization, its aims, values, occupation, and career. This also refers to the relative intensity of an individual's identification with and involvement in their career, acceptance of the profession's aims, and desire to invest effort on its behalf (Gill \& Kaur, 2017).

Affective professional commitment is the initial indicator of professional commitment. Affective professional commitment refers to an employee's emotional attachment to, identification with, and involvement in the employee's profession and its objectives in terms of the teacher's motivation to identify with and expectation not to abandon the profession for self-interested desires, compliance to work altruistically and contribute to the employee's profession's success, and eagerness to make special sacrifices - to go above and beyond normal potential and tolerance (Ware \& Kitsantas, 2016).

The affective professional commitment was defined as an individual's identity, emotional attachment, and involvement with the organization and its goals. The three components of affective professional commitment are (1) belief in and acceptance of the organization's objectives and standards, (2) readiness to exert effort to accomplish the organization's goals, and (3) a willingness to continue participation in the organization. These individuals have a great feeling of dedication to their careers (Ibrahim, 2015; Van der Werf, 2020).

Additionally, it was confirmed by meta-analyses that found affective commitment to be more significantly connected with absence than continuity or normative commitment (Cooper-Hakim \& Viswesvaran, 2005; Mercurio, 2017). Additionally, the affective commitment was associated with a broad range of behavioral factors, including assisting others, working additional hours, sharing information, and supervisor appraisal of performance (Solinger, 2008; Mansell, 2019).

It was stated that affective commitment happens when an employee wants to be dedicated to a specific goal. For instance, if an employee has a high level of affective commitment to the business, they will have a positive relationship with it and be more likely to stay. This dedication encourages employees to work attentively on their assigned responsibilities. It enables them to perform better in supporting their aims and objectives (Towler, 2020).

The second measure of professional commitment is continuance professional commitment. Professional commitment to continuation refers to a commitment based on "the rewards and costs associated with remaining in the profession." It is the degree to which an individual believes they must continue in their current occupation due to a lack of alternatives or the potential for disruptions if they leave. Economic imperatives are what keep professionals committed to their profession and its beliefs. Employees that maintain a high level of professional devotion remain in their profession since leaving incurs a substantial cost (Nazari \& Emami, 2017; Wang \& Saunders, 2018).

Additionally, continuing commitment refers to an individual's belief that leaving the organization would be costly. Suppose an individual possesses a high level of commitment to continuity. In that case, they will remain with an organization out of a sense of obligation. For instance, one may believe that quitting a job 
will result in an unacceptably long period of unemployment. On the other side, one may have a sense of loss of prestige if they depart a reputable institution (Grimsly, 2018).

Additionally, and perhaps most importantly, the third and final indicator of professional commitment is normative professional commitment. Normative professional commitment refers to individuals' emotions of moral obligation to remain in their career. The professional's sense of obligation upholds the profession's principles (Maheshwari, 2007; Williams, 2018).

Sociologists first noticed and analyzed the potential importance of normative professional commitment in working life, stating that commitment is promoted by service ideals and that the goal of leadership is to form these values. Individual commitment to an organization can be facilitated if religious, educational, or healthcare institutions are available to personnel (Bryson \& White, 2017).

Additionally, normative professional commitment is founded on the concept of an employee's sense of personal responsibility to the organization in which they work. This commitment is founded on the individual's ethical conviction that remaining in the organization is right and good. Individuals who have a strong normative commitment to an organization stay because they believe they should. It was explained that devoted employees remain with an organization, attend work consistently, work a full day and more, safeguard corporate assets, and believe in its aims (Meyer \& Allen, 2016).

To assess the employee is not only to know how one performs the job, to weigh their quality and performance in an organization is to normatively construct and shape the employee in ways that have reflective significances for communities and institutions (Luke \& Luke (2018). Employees' professionalism and perception about professional development and factors that affected their formation focused on some research. However, little was known about employees' views regarding these issues (Swann, 2016) as research has focused more on employees.

\section{Organizational Climate}

Another variable in this research is organizational climate, tacitly or explicitly referenced in some of the earliest works in organizational psychology as an alternative to the sole focus on individual characteristics that had characterized companies (Scheneider, 2016).

The first sign of organizational climate is mechanism, which indicates that progressive firms value respect for people through fairness, equality, and support for all employees. While the organization's values may theoretically support a progressive climate, the widespread climate that actually exists may not be experienced uniformly by all organization members. When perceived unfairness is directed towards a certain group, such as women, the organization may significantly lose production. This is why organizations must prioritize projects and processes for improving and enhancing their operations (Patel, 2017).

Additionally, individuals who work in an organization that fosters an environment where mistakes and failures are addressed through constructive ideas and methods for adjustment rather than punishment are more inclined to take the initiative and submit new ideas. Employee resilience is likely to moderate this process, as an organizational climate fosters employee resilience, which in turn encourages employees to determine their own futures and so behave pro-actively (Caniels \& Baaten, 2018). In other words, a learning-centered organizational culture fosters employee proactivity through employee resilience. This argument is based on social cognitive theory, which maintains that it is critical for human agency to manage one's own functioning and control the events that affect one's life (Bandura, 1989).

Additionally, trust, team spirit, and objectivity serve as the second indicator of organizational climate. While these are regarded to have a beneficial influence during the duration of a project, it is worthwhile to attempt to quantify their total benefit. A high level of trust between clients and project design teams minimizes transaction costs while increasing creativity and problem-solving capacity (Smith, 2019). These ideals will not easily deteriorate as a result of disagreements. These will also assist couples in overcoming obstacles and fostering mutual understanding (Bestieler 2016). Thus, trust, team spirit, and objectivity can all contribute to the strengthening and improving relationships between project partners, resulting in a variety of benefits for the project as a whole (Wong, 2018).

Similarly, the prevalence of trust, team spirit, and objectivity within an organization create a consistent work environment where employees have comparable expectations for appropriate behavior and are more likely to exhibit consistent behaviors. On the other side, a weak environment or a wide variety of employees' climate perceptions is likely to lead to inconsistent employee behavior, mostly determined by individual differences. Thus, the prediction of behaviors in weak and ambiguous climates is less reliable than in strong climates. 
This suggests that the association between climate quality and outcomes is likely to be less in weak climate settings than in good climate situations (Chaudhary, Rangnekar, \& Barua, 2018).

Autonomy, openness, and interpersonal relationships are the third indicator of organizational climate. These terms refer to the degree of transparency with task-related information (Schein 2017). These allow goal and expectation alignment and assist team members in developing a shared and mutual knowledge of the project's scope (McLeod \& MacDonell 2016). Open and adequate communication contributes to shared understanding, promotes the relationship's environment, fosters commitment, ensures deadlines are met and builds trust between the partners (Bestieler 2016; Zidane, 2016).

Additionally, transparency mitigates mistrust and conflicts of interest and enhances project performance (Turner \& Muller 2016). Organizational policies and procedures may impose limitations on adopting new standard processes, techniques, or tools. To overcome these obstacles, a project team should have an organizational culture that encourages individual initiative and ensures that necessary information is communicated and that direct communication between team members is maintained (McLeod \& MacDonell 2016).

Correspondingly, a positive organizational climate influences motivation, thus increasing employee performance. Organizational climate variables such as autonomy, openness, interpersonal relationship, and organization support and work commitment showed to be positively significant when related to organizational climate. A study conducted by Dawson, Gonzalez-Roma, Davis, \& West (2019) found a correlation of 67.2 percent, which showed a high impact of independent variables on the organizational climate.

Another measure of organizational climate is management belief and commitment, the fourth. These are the extent to which an individual identifies with and participates in an organization. It consists of three components: a deep commitment to and acceptance of the organization's goals and principles, a readiness to devote great work on behalf of the organization, and a desire to maintain membership. Belief and commitment are powerful and critical notions that have significant implications for both employees and organizations. Commitment to an organization represents a favorable relationship for employees (Mowday 2017). Belief in management as organizational support has a beneficial effect on attaining project objectives. Furthermore, organizational belief strengthens an individual's feeling of connectedness and belonging. This is critical for minimizing volatility and slippage in the cost and schedule of the project (Gulzar, 2018).

Employee attitudes influenced by management issues can impact the organization's values, atmosphere, and culture. Thus, motivation is the primary drive that motivates individuals to conceive and implement novel ideas. On the other hand, employees are driven to go beyond their assigned position and engage in spontaneous and inventive activities only if they have a deep connection to the organization. Under conditions of organizational change, organizational commitment can shift the focus away from organizational performance and toward employee contribution. This focus is warranted given the connection between commitment and critical outcomes such as job performance, organizational citizenship behaviors, readiness to share information, absenteeism, tardiness, and dissatisfaction (Chuang, 2016).

Training, development, and management support and encouragement are the fifth and final indicators of organizational climate. Ciplinski (2018) stated that perceptions of an employee's fairness in being considered for training and development are frequently at the base of why individuals quit firms. The concept of fairness is entwined in this issue, which means that support personnel will go above and above to achieve company goals or even their individual employment ambitions. As a result, firms must ensure that their employee training and development programs are founded on fairness principles. According to research, an employee's opinion of the fairness and equitable treatment is critical in determining retention, engagement, and performance. Indeed, inequitable treatment is corrosive.

The value of providing support and encouragement will improve an organization's performance. Organizations that use performance appraisal data to discover areas of strength and opportunity may also benefit. Performance appraisals can indicate areas of need for training and point toward effective leadership, performance enhancement, and succession planning (Richards, 2017).

According to Selden and Sowa (2016), performance appraisal findings can be analyzed to discover areas of high performance across all employees, by department, or by demographics. Standardized performance assessments enable businesses to aggregate, quantify, and evaluate outcomes to identify areas of strength. These areas of strength can serve as benchmarks and catalysts for sharing best practices across the firm. 


\section{Work Engagement}

Employee engagement can be defined as the process by which organizational members' selves are connected to their job roles. Individuals engage in engagement through utilizing and expressing themselves physically, cognitively, and emotionally. The purpose of this study is to ascertain the extent to which certain antecedents contribute to employee engagement (Kumar \& Sia, 2017).

Work engagement is not synonymous with organizational engagement. Employees can feel a sense of commitment to their businesses and jobs (Engelberg-Moston, 2019). Positive attitudes regarding their professions and organizations can influence employee engagement. These attitudes include a low level of intention to leave their job, job happiness, and organizational engagement (Schaufeli, Taris \& Van Rhenen, 2018). Work engagement is also associated with positive organizational behaviors such as self-initiative and motivation to learn, take on additional roles, and plan (Sonnentag, 2017; Salanova, Agut, \& Peiró, 2015).

Indeed, these elements can include employees' trust in their organizations. One could argue that trust is necessary for healthy relationships and interpersonal harmony. Trust is a state of believing and doing without hesitation, fear, or suspicion. Trust implies that one party in a relationship is confident that the other party will not take advantage of their vulnerability (Korczynski, 2016). In other words, it entails anticipating positive acts and attitudes on the part of others (Kramer, 2009; Costa, 2016).

Further, trust is a human feeling nourished and improved by mutual discussion, commitment, and action, and is a concept based on honesty and integrity in the most general sense (Ayaz-Yilmaz, 2016; Demircan \& Ceylan, 2003). Stakeholders in an organization also need to trust each other. Organizational trust is important for both stakeholders and organizations because problems will be encountered in attaining goals in an organization with trust issues (Yilmaz, 2016). Trust forms the basis of harmonious and productive relationships, effective cooperation, and communication within the organization (Baier, 2016).

Employee performance and productivity will improve in such an organizational environment. As a result, organizational trust can be considered a factor in determining an organization's level of effectiveness. Employee-built relationships based on trust with other internal stakeholders in the workplace can contribute to a sense of engagement with work. Engaged employees can also play a critical role in reshaping their schools into good and sustainable organizations (Ozer, 2006; Yilmaz, 2016).

There are no studies exploring the association between employees' perceptions of work engagement and organizational trust in the available literature. However, studies analyze the relationship between employees' perceptions of work engagement and organizational trust separately, or between work engagement and organizational trust and other variables (Yildiz, 2013; Sancak, 2016; Tumkaya \& Ustu, 2016).

Additionally, work engagement is defined in a different context as a positive, fulfilling state of mind associated with work characterized by vitality, dedication, and absorption (Schaufeli, Salanova, Roma, \& Bakker, 2017). Thus, engaged employees feel strong and vigorous at work, are enthusiastic and optimistic about their work, and are frequently immersed in it. Additionally, work engagement has been defined as "job involvement," which is defined as an employee's interest in, eagerness for, and funding in their job (Kirkpatrick, 2017).

Indeed, work engagement does not have the same connotation as organizational engagement. Employees can feel a sense of commitment to their businesses and jobs (Engelberg-Moston, 2019). It can be influenced by an employee's favorable attitude toward their job and organization. These attitudes include a low level of intention to leave their job, job happiness, and organizational engagement (Schaufeli, Taris \& Van Rhenen, 2018).

Additionally, work engagement is associated with a sense of commitment and investment in one's work performance and accomplishments, demonstrated through various work behaviors (MacTavish \& Kolb, 2016). Work engagement is also associated with positive organizational behaviors such as self-initiative and motivation to learn and take on additional roles and planning (Salanova, Agut, \& Peiró, 2015).

These factors can also include employees' trust in their organizations. One could argue that trust is necessary for healthy relationships and interpersonal harmony. Trust is a state of believing and doing without hesitation, fear, or suspicion. Trust implies that one party in a relationship is confident that the other party will not take advantage of their vulnerability (Korczynski, 2016). In other words, it entails anticipating positive acts and attitudes on the part of others (Kramer, 2009; Costa, 2016).

Additionally, trust is a human emotion that is nurtured and enhanced through mutual discussion, commitment, and action and is a concept that is founded on honesty and integrity in the broadest sense (Ayaz-Yilmaz, 2016; Demircan \& Ceylan, 2003). Stakeholders within an organization must also trust one 
another. Organizational trust is critical for stakeholders and organizations, as trust concerns impede an organization's ability to accomplish its goals (Yilmaz, 2016). The foundation of happy and productive relationships, good collaboration, and effective communication is trust (Baier, 2016).

Employees' performance and productivity will improve in a favorable work environment. As a result, organizational trust can be considered a factor in determining an organization's level of performance. Relationships that an employee develops with other colleagues based on trust can foster a sense of engagement with work. Engaged employees can also play a critical role in converting their company into a successful and efficient firm (Yilmaz, 2016).

The first sign for work engagement is cognitive work engagement. Cognitive work engagement is predicated on effectiveness, with the premise that people must work with rationality and awareness to be more effective. In theory, those cognitively engaged at work should have more positive attitudes about and attention to their work. Their cognitive processing of tasks would be frequent and intense, resulting in improved effectiveness. Thus, cognitive work engagement is defined here as the deliberate and active consciousness of one's tasks, objectives, or functions of the organization, characterized by voluntarily directing one's attention to and thinking positively about one's work to increase one's effectiveness at those tasks, objectives, or activities (Kuok \& Taormina, 2017).

Emotional work engagement is the second predictor of work engagement. Employee involvement can decline during economic dread and gloom as employees lose confidence and become frightened about the organization's future. Suppose an organization has made staff cuts or targets are not fulfilled. In that case, there can be a downward spiral effect on employee productivity, further eroding the firm's performance. However, when individuals are emotionally and psychologically invested in their work, the firm performs better. This has a cascading effect, as employees increase their level of engagement. When people are involved in better performance and future development, they acquire a deeper sense of ownership. Additionally, they become more enthused and supportive of what is occurring in their work environment (Boyd, 2016).

To elaborate, cognitive work engagement is a proxy for an employee's attitude to tasks and their psychological involvement in and willingness to understand complex subjects (Fredricks, 2017). Cognitive engagement, in particular, is based on ideas of goal orientation, cognitive strategy use, and self-regulation that have historically been associated with motivational processes and academic functioning (Cleary \& Zimmerman, 2017; Wolters \& Taylor, 2012).

Additionally, emotional work engagement is predicated on the concept of emotional labor at work, which refers to the process of managing one's emotions while at work. By and large, those who are emotionally invested in their work feel good or joyful about it. Experiencing such favorable effects provides them with pleasant thoughts about their employment. Thus, emotional work engagement is defined here as a willing connection to tasks, objectives, or organizational activities that are characterized by good sentiments about actively executing and achieving those tasks, objectives, or activities, such as pride, enthusiasm, and contentment (Grandey, 2000; Kuok \& Taormina, 2017).

The third sign of work engagement is physical work engagement, which demonstrates employees' current level of commitment to their jobs. (Kirkpatrick, 2017). It possesses vitality, commitment, and efficacy. However, engagement was defined as a pleasant, rewarding state of mind associated with work marked by vigor, devotion, and absorption. It is more than collaboration. It is the ability to maintain rapport with others (Cardwell, 2016).

Physical work engagement is predicated on the concept of bodily involvement in any activity. Individuals make physical efforts/use energy to perform things. While the amount of physical effort required to perform work varies by occupation, the concept of energy exertion at work remains relevant. For instance, a physically active industrial worker would be more energized during their work shift and finish assigned duties more quickly than other workers. Similarly, a physically engaged employee would be more likely to report to work and devote more effort to writing tasks that assist students in better comprehending the material of a lecture (Demerouti, Mostert, \& Bakker, 2015).

Furthermore, physical work engagement encompasses the amount of energy expended and the intensity or frequency with which energy and effort are expended at work. For instance, a football player who is extremely physically involved will run faster and exert more force to pressure opponents to gain possession of the ball. Thus, physical labor engagement is defined here as the intentional and voluntary use of one's 
energy and effort to execute and finish tasks, objectives, or organizational activities (Fredricks, Blumenfeld, \& Paris, 2017).

\section{Correlation between Measures}

Numerous studies have established the critical nature of employee engagement. The job entails resources model (JD-R model) supposes that work engagement occurs due to the intrinsic motivational nature of resources. Two available resources are distinguished: job resources, which are associated with organizational climate, and personal resources, which are defined as aspects of the self-connected with perseverance and refer to the ability to successfully control and influence one's environment, such as commitment to a job (Bakker \& Demerouti, 2008).

According to Bakker's (2009) idea of work engagement, an engaged employee has an extremely optimistic attitude characterized by inexhaustible vitality, energy, and a willingness to work and put effort. Engagement is a pleasurable, positive, affective-cognitive state. This implies that one must engage in life and be joyful, which was underlined by the philosophy of job engagement. Engaged individuals are receptive to new ideas, maintain physical and mental health, seek out their real abilities, and begin each day with vitality and vigor.

It is noted that the organizational atmosphere significantly impacts both professional dedication and work engagement (Uysal, 2018). The sincerity of connections among employees in an organizational climate is contingent upon employees' close ties and pleasant interactions with one another; close relationships and pleasant conversations with others influence employees' attitudes toward colleagues (Bayram \& Aypay, 2017).

Organizations require motivated employees to compete on a global scale. The importance of identifying indicators that predict organizational commitment has increased. Workplace commitment is one of the variables that might contribute to a positive organizational atmosphere, higher morale, motivation, and productivity.

Employees cannot perform their jobs due to unfavorable organizational climates at work, demonstrating that organizational climate has a significant effect on employee performance (Nurharani, Samsu, \& Kamalu, 2018). There is a significant association between organizational climate values and job satisfaction (Castro \& Martins, 2010) and between organizational climate and profitability, integrity, and involvement (Castro \& Martins, 2010). (Putter, 2010).

Meanwhile, the relationship between professional dedication and work engagement was examined using Demerouti, Bakker, Nachreiner, and Schaufeli (2015) and Hair, Anderson, Tatham, and Black (2014) investigations in summary, this research revealed a positive relationship between professional commitment and job engagement. Committed personnel demonstrates a strong commitment to the organization's goals and ideals, a readiness to invest significant effort on behalf of the employee, and a strong desire to maintain membership in the organization.

In another light, the organizational atmosphere has been demonstrated to predict job engagement. Bakker, Hakanen, Demerouti, and Xanthopoulou (2014) studied Finnish teachers to determine whether job demands increase workplace engagement when job resources are abundant. They found support for this hypothesis, and these types of demands are referred to as tough job demands. However, they included the organizational environment as a job resource and discovered that it was significantly connected to job engagement (Bakker \& Demerouti, 2017).

Finally, this study considers Chaudhary, Rangnekar, and Barua (2017) 's argument. Their study found support for partial mediation and mediating effects of occupational self-efficacy between a particular climate (human resource development) and work engagement. The moderating effect was stronger for people with low self-efficacy than those with high self-efficacy. Both of the studies cited above indicate that an organization's climate can help to increase employee engagement. However, there is a shortage of research on the relationship between the corporate atmosphere and employee engagement.

The related literature and studies provide the most needed knowledge and background on professional commitment, organizational climate, and work engagement as subjects under study, specifically on the relationship among these variables and how these variables and their indicators affect one another. The knowledge and concepts culled out from renowned scholars contribute much to the formulation of the theoretical framework and the questionnaire's development. 


\section{Theoretical Framework}

This study is based on Deci and Ryan's (1985) Self-Determination Theory, which examines the elements that influence employee motivation. This hypothesis was established and applied in professional and academic studies on employee engagement. As previously stated, employee engagement and individual behavior are related to the Self-Determination Theory. The ability of an employee to control specific behavior and goals determines their level of involvement. Employee behaviors encompass one's dedication and how one interacts with their environment.

Another theory that supports this study is Schneiderman's (1999) Theory of Engagement which is based on the idea that when employees find their work meaningful, have a high level of interest in the tasks, the working atmosphere is conducive, and employees have the commitment in managing their tasks. It was also emphasized that employees who want to increase their engagement level strengthen their commitment to their jobs and maintain a positive organizational climate (Funtowicz (2018).

The employee engagement theory (Hellivig, 2017) bears the current study. The theory emphasized that leaders of an organization ensure that all their staff members are fully engaged. To acquire such a goal, members must be fully committed, and a positive organizational climate must be maintained. In this study, being engaged simply means being committed, motivated, and enjoying a good working climate.

Additionally, this study is based on the Job Demands and Resources Model (JD-R model), which states that while each profession may have its own unique characteristics of work engagement, they can all be classified into one of two categories, namely job demands or job resources (Bakker \& Demerouti, 2017). Job requirements are stressful work that might result in a low level of commitment and a bad work climate over time (Garrosa, Moreno-Jiménez, Rodrguez-Muoz, \& Rodrguez-Carvajal, 2011). The second workplace environment is job resources, which pertains to those factors that can help reduce job demands and associated physiological and psychological costs, aid in achieving work goals or increase employee commitment, and contribute to the development of a positive organizational climate (Salanova, Del Lbano, Llorens, \& Schaufeli, 2018).

\section{Conceptual Framework}

As illustrated in Figure 1, the conceptual model for this study consisted of two relationships derived from two independent variables and one dependent variable. The study's independent variables are professional and organizational dedication. The variable of interest, on the other hand, is work engagement. Because these factors are not observed, they cannot be directly measured. This allowed for the association of each structure with measures of the observed variable. Thus, one of the key objectives of this study was to determine the length of regression routes connecting the independent factors to the dependent variable. One of the independent variables was professional commitment, which was quantified using three indicators: affective professional commitment, continuance professional commitment, and normative professional commitment (Bagraim, 2003). Affective professional commitment is defined as an individual's emotional attachment to and involvement with the organization and its objectives; continuance professional commitment is defined as an individual's proclivity to commit to a continuous line of activity. Normative professional commitment is defined as the idea of a sense of personal responsibility toward the organization in which employees operate.

Another control variable is organizational climate, which was quantified using different indicators: mechanism; trust, team spirit, and objectivity; autonomy, openness, and interpersonal relationships; management beliefs and commitment; and training, development, and management support and encouragement (Chaudhary, Rangnekar, \& Barua 2018). Mechanism refers to the steps undertaken on behalf of the group; trust, team spirit, and objectivity refer to the commitment and loyalty to the organization; autonomy, openness, and interpersonal relationships refer to the rapport that one has within the

organization; management belief and commitment refer to a firm conviction in an organization's goals and values, an eagerness to work together with the organization's interest, and a strong intention to maintain a member.

Meanwhile, the variable of interest was work engagement, as measured by three criteria: cognitive work engagement, emotional work engagement, and physical work engagement (Kuok \& Taormina, 2017). Cognitive work engagement is defined as the deliberate and active awareness of one's tasks, objectives, or 
organizational activities, which is characterized by voluntarily directing one's attention to and thinking positively about one's job to increase effectiveness. Employees' emotional work engagement relates to their feelings about their job and organization, increasing their job satisfaction. In contrast, physical work engagement relates to employees' body participation in any employment, as they put physical effort/energy into executing duties.

\section{Independent Variables}

IV1

\section{Professional Commitment}

- Affective Professional Commitment

- Continuance Professional Commitment

- Normative professional Commitment

\section{Organizational Commitment}

- mechanism;

- trust, team spirit, and objectivity;

- autonomy, openness, and interpersonal relationship;

- management beliefs and commitment; and

- training, development and management support and encouragement.

Figure 1. Conceptual Framework of the Study

\section{Significance of the Study}

In general, work engagement is consistently shown as something given by the employee that can benefit the entire organization through commitment, dedication, advocacy, discretionary effort, using talents to the fullest, and supporting the organization's goals and values. It can be noted that engaged employees feel a sense of attachment towards their organization, investing themselves in their role and the organization as a whole. Further, highly engaged employees are more likely to stay with the organization, perform better than their colleagues, and act as business advocates. Engagement can enhance bottom-line profit and enable organizational agility and improved efficiency in driving change initiatives (Smith \& Marwick, 2014).

This study can help the employees identify the factors that greatly contribute to work engagement. This will enable them to determine the best training needed by the employees to improve their work performance by strengthening their professional commitment and maintaining a positive organizational climate. This may also serve as an overall lookout of the organization; this may guide and assist employees in improving their working strategies to achieve greater work achievement. Also, DepEd employees being the focus of this study may find this study beneficial. This may give them adequate information to strengthen their work engagement. They may gain from this research since their work engagement will be boosted. Their commitment will be enhanced, eventually improving their working performance. Finally, future researchers 
may use the outcome of this study as a reference for deeper and wider research to explore variables not included in this study.

\section{Definition of Terms}

To facilitate comprehension of the concepts used in this work, the following terms are defined operationally: Professional Commitment. The phrase relates to a person's loyalty, desire to remain in a profession, and a sense of responsibility for the difficulties and challenges unique to that profession. This commitment can be quantified in affective commitment, continuance commitment, and normative commitment.

Organizational Climate. This study uses the phrase to refer to worker productivity, motivation, and conduct contingent on another individual's assessment. This can be demonstrated by mechanisms such as trust, team spirit, and objectivity; autonomy, openness, and interpersonal relationships; management beliefs and commitment; and training, growth, and management help and support.

Work Engagement. The term refers to the process through which organization members are harnessed to their work-related activities: during role performances, people employ and express themselves physically, cognitively, emotionally, and mentally. This might be measured in cognitive, emotional, or physical engagement with work.

\section{Method}

In this part of the study, the research steps and procedures employed are discussed. It includes the research design, the research locale, the population and sample, the research instrument, the data collection procedures, the statistical tools used, and the ethical consideration.

\section{Research Design}

This study employed a quantitative, non-experimental research approach with the express purpose of establishing correlations between variables. This is an organized approach to collecting and evaluating data from various sources. Quantitative research Study design entails applying computational, statistical, and mathematical techniques to arrive at conclusions. It is definitive in its objective since it attempts to quantify the problem and determine its prevalence by looking for outcomes that can be projected to a larger population (Labaree, 2017). This research design is appropriate for this study since it aims to ascertain the major impact of professional commitment and organizational climate on work engagement. Additionally, it is non-experimental in nature, as variables were investigated in their natural situations without being modified or altered (Relo, 2016).

The correlational design was utilized to characterize, analyze, and explain the relationship between professional dedication and job engagement and the association between organizational climate and work engagement. This technique was used to examine relationships between variables without controlling or manipulating them (Bhandari, 2021). There are two independent factors and one dependent variable in this study. Without modifying the independent variables, the influence of job engagement on the professional dedication and organizational climate was seen.

A causal model including regression or correlation analysis was applied in this investigation. This provides a robust theoretical foundation for the study's variables. Regression is the study of the relationship between a dependent and one or more independent variables; it observes changes in one variable due to unit changes in another variable(s) (Raja, 2019). Work engagement is related to professional commitment and organizational atmosphere in this scenario

\section{Research Locale}

This study was conducted at Davao de Oro public schools. The province is located in the Philippines' Mindanao Island's mid-eastern region. Compostela, Maragusan, Monkayo, Montevista, and New Bataan, as well as Laak, Mabini, Maco, Mawab, Nabunturan, and Pantukan. The province is divided into 237 barangays, each with a school. Davao de Oro has a total population of 736,107 people, according to the 2015 Census of Population and Housing (CPH).

The province's agriculture-based economy is thriving and consistently outperforms other provinces in the region, particularly in bananas and other high-value crops. It is mineral-rich and, together with Davao Oriental, is considered Mindanao's mineral powerhouse. According to a survey, most families in the province get their primary income from agriculture-related activities (The Golden One, 2021). 
From the different walks of life of people living in the area, teachers encountered diverse cultures and the environment from the populace. Apart from that, varied working issues were experienced by them. Engagement among teachers in the workplace needs concern as this has been identified to affect schools' working atmosphere and performance. This study was done in the entire Division of Davao de Oro, as shown in the map in Figure 2. This study was conducted from December 2020 to February 2021.

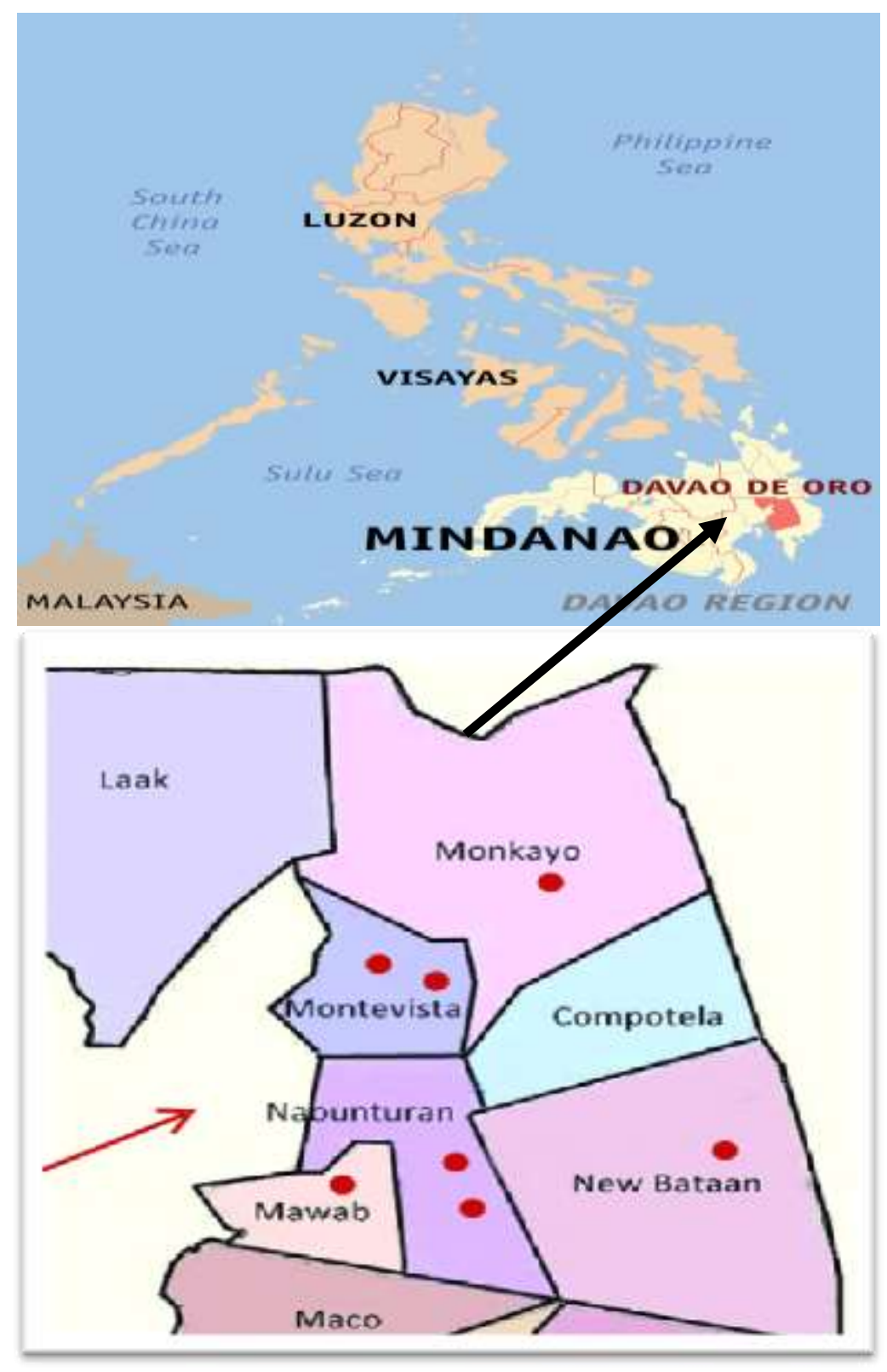

Figure 2. Map of the Philippines and Davao de Oro

\section{Population and Sample}

The study surveyed 312 non-teaching professionals from the Department of Education, Davao de Oro Division, comprising 137 male and 175 female respondents. The respondents were chosen because they could provide the relevant data and information for the present study; thus, this study focused on the impact of professional dedication and organizational climate on non-teaching personnel's work engagement. While these individuals may differ in specific qualities and attitudes toward their jobs, they have a common experience (Laerd Dissertation, 2018) as non-teaching professionals in DepEd's Davao de Oro Division public schools.

The researcher used a simple random sampling technique to ascertain the total number of non-teaching workers employed in each institution. The rule of thumb was used to select respondents suitable for the 
study (Bentler, Yuan, \& Eu, 2010), which states that the researcher prefers to work with the correct sample size per strata in quota sampling (Changing Minds, 2017). Additionally, information gleaned from the entire community provided a more complete picture of a target demographic than partial samples could. It can enable researchers to build a far more complete picture and significantly minimize the amount of guesswork. Additionally, it reduces the potential of biased sample selection that frequently occurs in purported random study samples (Crossman, 2018).

Respondents may be removed from the research study if they are found to have committed falsification, plagiarism, or other moral violations or if they have a medical condition or specialized need. Additionally, participants may withdraw from the research at any point if they are upset or uncomfortable. If this is the case, volunteers should notify the researcher of their withdrawal. A participant may notify the researcher with their reason(s) for withdrawing from the study. However, they are not compelled to do so.

\section{Research Instrument}

Three (3) sections comprised the questionnaire survey that served as the study's instrument. The first section is based on Bagraim's (2003) Questionnaire on Professional Commitment. The questionnaire is composed of fifteen items. Each item was scored using a five-point Likert Scale ranging from Strongly Disagree to Strongly Agree. The original questionnaire was adapted to reflect the work environment. Experts verified the redesigned questionnaire with a mean score of 4.15 or Very Good. The pilot study was conducted with a Cronbach alpha of.880.

The following range of means was used in describing the level of professional commitment.

\section{Range of Means Descriptive \\ Level}

\section{Interpretation}

4.20 - 5.00 Very High Professional commitment is always manifested.

3.40-4.19 High Professional commitment is often manifested.

2.60-3.39 Moderate manifested.

$1.80-2.59 \quad$ Low $\quad$ Professional commitment is seldom manifested.

1.00-1.79 Very Low Professional commitment is never manifested.

The second section of the survey consisted of the Organizational Climate Questionnaire adapted from Chaudhary and Barua (2013). It consisted of 38 things measuring five structures condensed into 25 items. The original questionnaire was adapted to reflect the work environment. Each item was assigned a score on a five-point Likert Scale ranging from Strongly Disagree to Strongly Agree. As with the first section, experts verified the amended questionnaire with a mean score of 4.15 or Very Good, and pilot testing yielded a Cronbach Alpha of.915. following:

. The following range of means was used in describing the level of organizational climate are the

\begin{tabular}{|l|l|l|}
\hline Range of Means & \multicolumn{1}{|c|}{$\begin{array}{c}\text { Descriptive } \\
\text { Level }\end{array}$} & \multicolumn{1}{c|}{ Interpretation } \\
\hline $4.20-5.00$ & Very High & Organizational climate is always observed. \\
\hline $3.40-4.19$ & High & Organizational climate is often observed. \\
\hline $2.60-3.39$ & Moderate & Organizational climate is sometimes observed. \\
\hline
\end{tabular}




\begin{tabular}{|l|l|l|}
\hline $1.80-2.59$ & Low & Organizational climate is seldom observed. \\
\hline $1.00-1.79$ & Very Low & Organizational climate is never observed. \\
\hline
\end{tabular}

Additionally, the final section included the Work Engagement Questionnaire (Kuok \& Taormina, 2017). Additionally, the original questionnaire was updated to fit the work environment. Each item was assigned a score on a five-point Likert Scale ranging from Strongly Disagree to Strongly Agree. As with the two components, the redesigned questionnaire was validated by experts and received a mean score of 4.30 or Very Good during pilot testing.

The following range of means was used in describing the level of role work engagement:

\begin{tabular}{|l|l|l|}
\hline Range of Means & \multicolumn{1}{|c|}{$\begin{array}{c}\text { Descriptive } \\
\text { Level }\end{array}$} & \multicolumn{1}{c|}{ Interpretation } \\
\hline $4.20-5.00$ & Very High & Work engagement is always manifested. \\
\hline $3.40-4.19$ & High & Work engagement is often manifested. \\
\hline $2.60-3.39$ & Moderate & Work engagement is sometimes manifested. \\
\hline $1.80-2.59$ & Low & Work engagement is seldom manifested. \\
\hline $1.00-1.79$ & Very Low & Work engagement is never manifested. \\
\hline
\end{tabular}

After expert validation, an average mean rating of 4.20 or Average was obtained, as was reliability. The instruments were pilot tested with 40 samples from a nearby division and received a Good Cronbach Alpha for all variables.

\section{Data Collection}

The researcher underwent different procedures in the conduct of the study. First, the researcher sent a letter of permission to conduct the study to the Department of Education- Davao de Oro Division from the Dean of the Graduate School as proof that this research was officially acknowledged by the University of Mindanao which was sent to the Schools Division Superintendent, District Supervisor and School Heads of the schools' concern. The letter's purpose is to seek permission to study the influence of professional commitment and organizational climate on work engagement among the non-teaching employee of the Department of Education in the Davao de Oro Division.

Upon the approval of the office heads, the researcher sent and distributed the Informed Consent Form (ICF) to the participants asking them permission to be part of the study face to face and online. It cannot be denied that employees were not participative in the study. Nevertheless, the researcher explained the study's purpose and ensured maximum confidentiality. Then, the researcher administered the questionnaire to the participants using google form and achieved 100 percent retrieval after a series of follow-ups among all the respondents. Then, a Certificate of Appearance was secured from the office heads concerned to vouch that the researcher honestly collected the data from the study participants. The accomplished results were then tabulated, checked, and tallied. Finally, after all the results were tallied, these were analyzed and interpreted based on the purpose of the study.

\section{Statistical Tools}

The following statistical tools were used in interpreting the data that were gathered.

Mean. This was used to characterize professional commitment, organizational climate, and work engagement which addressed the first, second, and third research objectives.

Pearson's r. This statistical tool was used to determine the significance of the relationships between professional commitment and work engagement and organizational climate and work engagement. This is in answer to research question number 4. 
Regression. This was used to determine the significant influence of professional commitment and organizational climate to work engagement. This is in answer to research question number 5 .

\section{Ethical Considerations}

This study aimed for a high-quality effect ensuring the integrity of all data gathered. Human legislation was obeyed, and data protection was observed. Thus the name and other data are optional. Respondents of the survey conducted voluntarily filled up the Google survey form questionnaires, assured their rights and privacy were protected, and responses were strictly used for the study. This was done to confirm that this research considered ethical considerations. Research papers may even be doomed to failure if this part is missing. Research ethics is mainly concerned with analyzing ethical issues raised when people are involved in research (Walton, 2017). To ensure integrity, quality, and transparency, this research was reviewed and undertaken following commonly agreed standards of good research practices.

Voluntary Participation. This research entailed voluntary participation, which ensured that the participants were willing to be involved in the investigation after fully knowing the purpose of the study. The participants were allowed to read the information first and ask anything they did not know before participating. They were also given enough time to think about their participation.

Privacy and Confidentiality. This also safeguarded and guaranteed the privacy and confidentially of participants' information. The researcher kept the study records confidential to protect the rights and welfare of participants involved in the study. The researcher also provided a Non-disclosure Agreement (NDA) to protect the integrity and confidentiality of both parties.

Informed Consent. Further, this study underwent the informed consent process applying the principle of respect for the person, who may solicit consent, how and when it will be done. This study was done in the form of consent from the participants themselves to voluntarily signify their willingness to become a part of the study.

Recruitment. For this research, the appropriate identified recruiting parties were the schools' division superintendent since the target respondents are the non-teaching personnel of the Department of Education. They were the ideal partners of the investigator to achieve well-established working relationships with the selected respondents. Such partnership could be expected to provide greater awareness of the importance of this research study.

Risks. The researcher assumed that this research involves minimal risk. The probability and magnitude of possible harms implied by participation in the research are no greater than those encountered by participants in those aspects of their everyday life related to the research. However, for this research, the researcher has a higher risk of getting harmed through physical injury or physiological harm due to traveling to different locations where this research project covers. The researcher evaluated the risks and decided on the precautions such as maximum health and safety travel protocols were followed to mitigate this. Travel was done with a companion, awareness of options for mode of travel, awareness of physical environments like alleyways, open spaces, and awareness of health and safety policies of research locations.

Benefits. This study also ensured the obligation of the investigator or researcher to maximize the benefits as stated in the significance of the study while minimizing the risk of harm of the research for the individual participants and/or society involved.

Plagiarism. Additionally, the researcher warranted no trace of evidence of misrepresentation of someone else's work as his own. To make this certain, the use of Turnitin software and/ or Plagiarism Detector will be in place.

Fabrication. Moreover, this research showed no trace/ evidence of intentional misrepresentation of what has been done, no making of data and/ or results, or purposefully putting forward conclusions that are not accurate and no inconsistency with the existing literature among the information included in the manuscript.

Falsification. Furthermore, no trace of purposefully misrepresenting the work to fit a model or theoretical expectation, and no evidence of overclaiming or exaggerations on this research appeared.

Conflict of Interest. Similarly, there was no trace of conflict of interest (COI), for disclosure of COI was evident in this study. COI is a set of conditions in which a professional judgment concerning primary interest such as the participant's welfare or the validity of the research tends to be influenced by a secondary interest such as financial or academic gains or recognitions.

Deceit. In essence, the falsehood about the author's identity and the nature and true purpose of the study should be avoided; this research does not use deception. To deceive is to deliberately mislead others. This 
issue is most relevant in experimentation where personal knowledge of the purposes might change people's behavior; hence this is not applicable for this study.

Focus Group Participant Identification. Also, to address the fact that the information discovered within the group becomes common knowledge among those in attendance, this research included a provision in the consent form reminding participants to keep the information discussed confidential.

Permission from Organization/Location. Notably, the researcher ensured to get written permission from the organization in which the research was undertaken or the location in which the data were collected and made sure that when getting written permission, the person to talk to must have the authority to give the permission sought and that the activities are organized well in advance. In this study, the permission was addressed to the School Division Superintendent and the Head of Offices of non-teaching employees who became respondents to this study.

Technology Issues. In this study, provisions as to the use of online panels, collection of data online, and how one views the information being communicated in an online environment were put in place and are made understandable to the participants before data collection was done. In this study, Google form was used to gather data for the research. Aside from sending the form online, the researcher called some respondents, informing them that the survey was already sent to their emails/ messenger. This was backed up by a series of follow-ups to retrieve the data. Doing the survey online needs a good internet connection.

Authorship. As can be seen, the author of this research is the one whose name appeared on the title page of this manuscript. Her study will undergo a series of content revisions due to recommendations made by her adviser. The study followed the standards of the University of Mindanao Ethics Review Committee for the guidelines of ethical consideration. After their approval, the study underwent pilot testing. The data collected were interpreted for the consistency of the research questionnaire. With the assistance of her adviser as co-author, the author of this research manuscript contributed mentally and spiritually to the scientific content and shaped the research aspect into a presentable and understandable form.

\section{Results}

As a result of those discoveries, the data and analysis in this chapter are presented. Professional commitment and organizational environment are discussed in order of importance: the relationship between these two variables and work engagement; the relationship between these two variables and work engagement; the influence of predictors on work engagement.

\section{Level of Professional Commitment}

The primary goal of this research was to find out how committed non-teaching staff at the Division of Davao de Oro were to their jobs. The professional commitment was measured in affective, continuance, and normative professional commitments, respectively. According to the survey, the level of professional devotion is depicted in Table 1. There is an overall mean of 4.42 or a very high level of professional devotion, with a standard deviation of 0.581 . There is a constant display of professional commitment here.

To summarize, the emotional professional commitment had a mean score of 4.65 , with a standard deviation of 0.514 percent, making it the most common type of professional commitment. As a result, the mean rating of 4.32 for normative professional commitment, with a standard deviation of 0.581 , was followed by 4.30 for continuation professional commitment with a mean rating of 4.30 .

Table 1 : Level of Professional Commitment

\begin{tabular}{|c|c|c|c|}
\hline Indicators & SD & Mean & $\begin{array}{c}\text { Descriptive } \\
\text { Level }\end{array}$ \\
\hline Affective Professional Commitment & 0.514 & 4.65 & Very High \\
\hline Continuance Professional Commitment & 0.555 & 4.30 & Very High \\
\hline Normative Professional Commitment & 0.581 & 4.32 & Very High \\
\hline Overall & 0.581 & 4.42 & Very High \\
\hline
\end{tabular}

\section{Level of Organizational Climate}


To measure the level of organizational climate of non-teaching personnel in the Division of Davao de Oro, we used a survey questionnaire that included the following indicators: mechanism; trust, team spirit, and objectivity; autonomy; openness; interpersonal relationships; and managerial belief, commitment, and encouragement. Table 2 shows the results of the organizational climate which was calculated to have a grand mean of 4.28 and a standard deviation of 0.503 , which indicates that the statements of the organization's climate are always present. A number of factors contribute to a positive work environment, which has mean values of 4.20 to 4.34 . The typical scores are 4.34 for trust, team spirit, and objectivity; 4.30 for mechanism and managerial belief and dedication; and 4.34 for training, development, managerial assistance, and encouragement. 25; as well as freedom, honesty, and trust in other people at 4.20.

Table 2 : Level of Organizational Climate

\begin{tabular}{|l|c|c|c|}
\hline Indicators & SD & Mean & $\begin{array}{c}\text { Descriptive } \\
\text { Level }\end{array}$ \\
\hline Mechanism & 0.592 & 4.30 & Very High \\
\hline Trust, Team Spirit, and Objectivity & 0.529 & 4.34 & Very High \\
\hline Autonomy, Openness, and Interpersonal Relationships & 0.553 & 4.20 & Very High \\
\hline Managerial Belief and Commitment & 0.548 & 4.30 & Very High \\
\hline $\begin{array}{l}\text { Training, Development, Managerial Support and } \\
\text { Encouragement }\end{array}$ & 0.622 & 4.25 & Very High \\
\hline \multicolumn{1}{|c|}{ Overall } & $\mathbf{0 . 5 0 3}$ & $\mathbf{4 . 2 8}$ & Very High \\
\hline
\end{tabular}

\section{Level of Work Engagement}

The third objective of this study, as reflected in Table 3, was to ascertain the level of work engagement of non-teaching employees in the Division of Davao de Oro. This was actually achieved by using a survey questionnaire that included the following components: cognitive work engagement, emotional work engagement, and physical work engagement.

Table 3 : Level of Work Engagement

\begin{tabular}{|l|c|c|c|}
\hline Indicators & SD & Mean & $\begin{array}{c}\text { Descriptive } \\
\text { Level }\end{array}$ \\
\hline Cognitive Work Engagement & 0.534 & 4.34 & Very High \\
\hline Emotional Work Engagement & 0.547 & 4.37 & Very High \\
\hline Physical Work Engagement & 0.565 & 4.28 & Very High \\
\hline \multicolumn{1}{|c|}{ Overall } & $\mathbf{0 . 5 0 8}$ & $\mathbf{4 . 3 3}$ & Very High \\
\hline
\end{tabular}

The overall level of work engagement was 4.33 , which is extremely high, with a standard deviation of 0.508 , indicating that the work engagement assertions are consistently manifested. The mean scores for indicators that contributed to the extremely high degree of work engagement range from 4.28 to 4.37.

From highest to lowest, the criterion and its mean ratings are as follows: emotional work engagement, 4.37 or very high, with a standard deviation of 0.547 ; cognitive work engagement, 4.34 or very high, with a standard deviation of 0.534 ; and physical work engagement, 4.28 or high, with a standard deviation of 0.565 .

\section{Significance of the Relationship between}

Professional Commitment and Work Engagement.

As stated in Table 4.1, one of the most critical objectives of this study was to establish if professional dedication is significantly associated with job engagement among non-teaching professionals in the Division of Davao de Oro. 
Table 4.1 : Significance of the Relationship between Levels of Professional Commitment and Work Engagement

\begin{tabular}{|l|c|c|c|c|}
\hline \multicolumn{1}{|c|}{$\begin{array}{c}\text { Professional } \\
\text { Commitment }\end{array}$} & \multicolumn{3}{|c|}{ Work Engagement } & \\
\cline { 2 - 5 } & $\begin{array}{c}\text { Cognitive Work } \\
\text { Engagement }\end{array}$ & $\begin{array}{c}\text { Emotional } \\
\text { Work } \\
\text { Engagement }\end{array}$ & $\begin{array}{c}\text { Physical Work } \\
\text { Engagement }\end{array}$ & Overall \\
\hline $\begin{array}{l}\text { Affective } \\
\text { Professional } \\
\text { Commitment }\end{array}$ & $.625^{*}$ & $.637^{*}$ & $.588^{*}$ & $.655^{*}$ \\
\hline Continuance & $(0.000)$ & $(0.000)$ & $(0.000)$ & $(0.000)$ \\
$\begin{array}{l}\text { Professional } \\
\text { Commitment }\end{array}$ & $.549^{*}$ & $.532^{*}$ & $.564^{*}$ & $.592^{*}$ \\
\hline $\begin{array}{l}\text { Normative } \\
\text { Professional }\end{array}$ & $(0.000)$ & $(0.000)$ & $(0.000)$ & $(0.000)$ \\
Commitment & $.542^{*}$ & $.521^{*}$ & $.561^{*}$ & $.584^{*}$ \\
\hline Overall & $.0 .000)$ & $(0.000)$ & $(0.000)$ & $(0.000)$ \\
\hline
\end{tabular}

The correlation coefficient between instructors' professional dedication and work engagement was 0.708 , with a probability value of 0.000 or significant. Because the p-value was less than 0.05 , there was even a significant association between non-teaching personnel's professional dedication and work engagement in the Division of Davao de Oro. As a result, the null hypothesis that no significant relationship existed between professional commitment and work engagement was rejected.

When the domains of professional commitment were associated with total work engagement, the results indicated that emotional, professional commitment is strongly associated with an employee working competence, with an r-value of 0.655 and a probability value of $\mathrm{P} 0.05$ or significant. When the domain continuance professional commitment was correlated with work engagement of Department of Education personnel in the Division of Davao de Oro, the results indicated an r-value of 0.592 with a probability value of $\mathrm{P} 0.05$ or significant, and a mean rating of 0.584 with a probability value of $\mathrm{P} 0.05$ or significant.

Meanwhile, when the domains of work engagement were correlated with overall professional commitment, the results indicated that cognitive work engagement was strongly associated with professional commitment, with an r-value of 0.660 and a probability value of $\mathrm{P} 0.05$ or significant. When emotional work engagement and work engagement were connected, the outcome was an $\mathrm{r}$-value of 0.649 with a likelihood value of $\mathrm{P}$ 0.05 or significant. Physical labor involvement was assigned a mean score of 0.660 , with a probability value of P 0.05 or significant.

\section{Significance of the Relationship between Levels of \\ Organizational Climate and Work Engagement}

The association between the organizational atmosphere and work engagement was demonstrated in Table 4.2. The findings indicate a substantial association between organizational environment and work engagement, as evidenced by the correlation coefficient's overall value of 0.719 with a probability value of 0.000 or significant.

When the domains of organizational climate were correlated with work engagement, the correlation coefficient for the indicator mechanism had a mean rating of 0.656 ; trust, team spirit, and objectivity had a mean rating of 0.292; autonomy, openness, and interpersonal relationship had 0.574managerial belief and commitment had 0.664, and training, development, managerial support, and encouragement had 0.658. Results implied that organizational climate had a strong correlation among all domains of work engagement. All domains were significantly correlated, as reflected in all the probability values less than 0.05 .

Table 4.2 : Significance on the Relationship between Levels of Organizational Climate and Work Engagement 


\begin{tabular}{|c|c|c|c|c|}
\hline \multirow{2}{*}{$\begin{array}{c}\text { Organizational } \\
\text { Climate }\end{array}$} & \multicolumn{3}{|c|}{ Work Engagement } & \multirow[b]{2}{*}{ Overal } \\
\hline & $\begin{array}{c}\text { Cognitive } \\
\text { Work } \\
\text { Engagement }\end{array}$ & $\begin{array}{c}\text { Emotional } \\
\text { Work } \\
\text { Engagement }\end{array}$ & $\begin{array}{c}\text { Physical Work } \\
\text { Engagement }\end{array}$ & \\
\hline Mechanism & $\begin{array}{c}.655^{*} \\
(0.000)\end{array}$ & $\begin{array}{c}.592 * \\
(0.000)\end{array}$ & $\begin{array}{c}.579 * \\
(0.000)\end{array}$ & $\begin{array}{l}.656^{*} \\
(0.000)\end{array}$ \\
\hline $\begin{array}{l}\text { Trust, Team } \\
\text { Spirit, and } \\
\text { Objectivity }\end{array}$ & $\begin{array}{c}.595^{*} \\
(0.000)\end{array}$ & $\begin{array}{l}.578^{*} \\
(0.000)\end{array}$ & $\begin{array}{c}.560 * \\
(0.000)\end{array}$ & $\begin{array}{l}.623^{*} \\
(0.000)\end{array}$ \\
\hline $\begin{array}{l}\text { Autonomy, } \\
\text { Openness, and } \\
\text { Interpersonal } \\
\text { Relationships }\end{array}$ & $\begin{array}{l}.567^{*} \\
(0.000)\end{array}$ & $\begin{array}{l}.517^{*} \\
(0.000)\end{array}$ & $\begin{array}{l}.513^{*} \\
(0.000)\end{array}$ & $\begin{array}{l}.574^{*} \\
(0.000)\end{array}$ \\
\hline $\begin{array}{l}\text { Managerial } \\
\text { Belief and } \\
\text { Commitment }\end{array}$ & $\begin{array}{c}.625^{*} \\
(0.000)\end{array}$ & $\begin{array}{l}.610^{*} \\
(0.000)\end{array}$ & $\begin{array}{c}.611^{*} \\
(0.000)\end{array}$ & $\begin{array}{l}.664^{*} \\
(0.000)\end{array}$ \\
\hline $\begin{array}{l}\text { Training, } \\
\text { Development, } \\
\text { Managerial Support } \\
\text { and Encouragement }\end{array}$ & $\begin{array}{l}.658 * \\
(0.000)\end{array}$ & $\begin{array}{l}.571 * \\
(0.000)\end{array}$ & $\begin{array}{l}.601 * \\
(0.000)\end{array}$ & $\begin{array}{l}.658^{*} \\
(0.000)\end{array}$ \\
\hline Overall & $\begin{array}{c}.703^{*} \\
(0.000)\end{array}$ & $\begin{array}{c}.649^{*} \\
(0.000)\end{array}$ & $\begin{array}{c}.648^{*} \\
(0.000)\end{array}$ & $\begin{array}{c}.719^{*} \\
(0.000)\end{array}$ \\
\hline
\end{tabular}

*Significant at 0.05 significance level.

Meanwhile, when domains of work engagement were correlated with organizational climate, the following correlation coefficients were revealed: cognitive work engagement, 0.703; emotional work engagement, 0.649; and physical work engagement, 0.648. All correlations have probability values of less than 0.05 or significant.

\section{The Extent of the Influence of Predictor Variables on Work Engagement}

Shown in Table 5 are the regression coefficients to test the significant influence of the overall professional commitment and organizational climate on work engagement. Using the regression analysis, the data revealed that the generally professional commitment and organizational climate significantly influences work engagement since the influence of professional commitment and organizational climate have the $F$ value 234.154 and $P<0.05$. The $R 2$ value of 0.610 implies that 61 percent of the professional commitment and organizational climate were due to the variation in work engagement. The 39 percent is influenced by other factors not covered in this study. The P<0.05 signifies the rejection of the null hypothesis set in the early part of this study. Specifically, the data revealed that professional commitment and organizational climate significantly influence work engagement, which has values of 0.000 which are less than the alpha value, which is 0.05. Meanwhile, in its singular capacity, organizational climate best influences work engagement with the highest beta coefficient of 0.448. However, professional commitment can also influence work engagement but with the support of other variables.

Table 5 : Regression Analysis on the Influence of Professional Commitment and Organizational Climate on Work Engagement

\begin{tabular}{|l|c|c|c|c|}
\hline \multicolumn{5}{|c|}{ Work Engagement (Dependent Variables) } \\
\hline Independent Variables & $\begin{array}{c}\boldsymbol{\beta} \\
\text { (Standardize } \\
\mathbf{d} \\
\text { Coefficients) }\end{array}$ & $\begin{array}{c}\text { B } \\
\text { (Unstandardiz } \\
\text { ed } \\
\text { Coefficients) }\end{array}$ & T & Sig. \\
\hline Constant & .469 & .181 & 2.598 & .010 \\
\hline
\end{tabular}




\begin{tabular}{|l|c|c|c|c|c|}
\hline \multicolumn{2}{|l|}{ Professional Commitment (PC) } & .411 & .439 & 8.441 & .000 \\
\hline \multicolumn{2}{|l|}{ Organizational Climate (OC) } & .443 & .448 & 9.102 & .000 \\
\hline $\mathrm{R}$ & & .781 & & & \\
\hline $\mathrm{R}^{2}$ & & .610 & & & \\
\hline $\mathrm{F}$ & & 234.154 & & & \\
\hline$P$ & & .000 & & & \\
\hline
\end{tabular}

\section{Discussion}

This chapter presents the discussion, conclusion, and recommendations based on the results of the study.

\section{Professional Commitment}

The overall level of professional commitment is very high, which means that professional commitment itemstatements were manifested at all times. This further implies that non-teaching personnel is happy and proud of their profession. Findings also implied that they make an effort to stay in the profession and are satisfied. They are loyal and feel responsible for remaining with the profession, and are open to learning opportunities in the teaching profession.

The study's findings also corroborate various writers' assertions (Nazari \& Emami, 2012; Gill \& Kaur, 2017) that personnel is willing to go above and beyond to ensure that work is successful. They lend assistance to others in their spare time, cooperate with and are willing to work with others, and profitably utilize work time. They exhibit good behaviors that benefit the organization and, as a result, are less likely to engage in activities that are detrimental to the business. They demonstrate a strong commitment to their profession, embrace its aims, and a desire to invest effort on its behalf.

\section{Organizational Climate}

The overall level of organizational climate is very high, which means that the organizational climate statements are manifested at all times. This further implies that non-teaching personnel-respondents have strong potential in maintaining a good working atmosphere. The item-statements contribute to the very high level of organizational climate: taking training seriously to learn from the programs attended, being delegated with work to prepare us for higher responsibilities, and top management believes that human resources are essential resources.

This is consistent with other writers' assertions (Chaudhary, Rangnekar, \& Barua, 2018; Patel, 2017; Caniels $\&$ Baaten, 2018) that non-teaching personnel has a progressive culture that values respect for individuals through fairness, equality, and support for all employees. They consistently construct a work atmosphere and have identical expectations for appropriate behavior. Hence, they are more likely to exhibit consistent behaviors. They are encouraged to shape their own futures and take a proactive role in achieving the organization's aims and ambitions.

McLeod and MacDonell (2016) and Schein (2017) concur with the study's findings, emphasizing the importance of committed professionals being transparent in communicating task-relevant knowledge. These commitments enhance objective and expectation alignment and assist team members in developing a shared and mutual knowledge of the project's scope. Non-teaching people benefit from fairness since they have equal access to training and development opportunities, which are frequently why employees leave firms. The concept of fairness is entwined in this issue, which means that supportive personnel will go above and beyond the call of duty to accomplish company goals or even their personal, professional ambitions.

\section{Work Engagement}

Work engagement is quite high. All factors were rated as very high by non-teaching respondents, which contributed to the extremely high degree of work engagement. Cognitive work engagement, emotional work engagement, and physical work engagement are the indications. The item-statements: being satisfied with one's job, being enthusiastic about one's work, and being completely involved in one's work all contribute to the extremely high degree of work engagement. 
This finding is consistent with Kumar and Sia's (2017) assertion that non-teaching people are extremely committed to their organizational work positions. They use and express themselves physically, mentally, and emotionally while performing their assigned jobs. They exhibited favorable opinions regarding their employment and employers. Additionally, the information gathered from several authors (Schaufeli, Taris, \& Van Rhenen, 2018; Sonnentag, 2017; Salanova, Agut, \& Peiró, 2015; Kramer, 2009; Costa, 2016; Yilmaz, 2016) correlates with the study's findings because they emphasize that work-engaged individuals have a low level of intention to leave their job. Work engagement is also associated with desirable organizational behaviors such as self-initiative and a desire to learn, taking on extra duties, and planning. They anticipate favorable behaviors and attitudes from others that will aid in launching efforts toward corporate success. Additionally, it meant that employees could convert their workplace into a profitable and efficient enterprise.

\section{Significance of the Relationship between \\ Professional Commitment and Work Engagement}

The correlation between professional commitment and work engagement showed a strong significant relationship. This implies that professional commitment is correlated with the work engagement of nonteaching personnel. This means that professional commitment affects work engagement. This could mean that how personnel manages their work determine their commitment. On the contrary, employees with a low management system may have low commitment.

This study's finding corroborates the assertions of Demerouti, Bakker, Nachreiner, and Schaufeli (2015) and Hair, Anderson, Tatham, and Black (2014) that organizational commitment and work engagement are positively related. Committed personnel demonstrates a strong commitment to the organization's goals and ideals, a readiness to invest significant effort on behalf of the organization, and a strong desire to maintain membership in the organization.

\section{Significance of the Relationship between Organizational Climate and Work Engagement}

The correlation between the organizational climate and work engagement showed a strong significant relationship. This implies that organizational climate is correlated with the work engagement of nonteaching personnel. This means that organizational climate affects work engagement. This could mean that the work environment's atmosphere, which is made up of its climate, can determine their work engagement. As implied, they enjoy a good relationship, provision of work resources, and disciplined and respectful staff manifest a positive organizational climate that enhances work engagement as they become motivated to improve their tasks.

This finding is consistent with Bakker, Hakanen, Demerouti, and Xanthopoulou's (2014) finding that organizational atmosphere predicts work engagement. They discovered that commitment improves work engagement when job resources are abundant, and they discovered evidence to support this idea. Meanwhile, another study examined organizational climate as a job resource and discovered a substantial relationship with job engagement (Bakker \& Demerouti, 2017). In addition, Schneiderman's (1999) Theory of Engagement bears this study, which implied that when employees are engaged and find their work meaningful, have a high level of interest in the tasks, the working atmosphere is conducive, and employees have the commitment in managing their tasks. It was also emphasized by Funtowicz (2008) that employees who work to increase their level of engagement strengthen their commitment to their jobs and want to maintain a positive organizational climate.

\section{Significance of the Extent of Influence of Predictor Variables on Work Engagement}

A regression analysis was employed to determine the influence of professional commitment and organizational climate on work engagement. Data revealed that the overall professional commitment and organizational climate significantly influence work engagement. The employee engagement theory of Hellivig (2017) validates the current study. The theory emphasized that if members in an organization are fully engaged, goals can be achieved easily. In order to have an engaging workplace, members must be fully committed, and a positive organizational climate must be maintained. He also emphasized that being engaged simply means being committed, motivated, and enjoying a good organizational climate. 
To that end, the Job Demands and Resources Model (JD-R model) is relevant to the study, as it states that while each occupation has its own unique characteristics of work engagement, they may typically be classified into one of two categories, namely job demands or job resources (Bakker \& Demerouti, 2017). Job demands cause stress, which in turn can result in a low level of commitment and a negative work climate (Garrosa, Moreno-Jiménez, Rodrguez-Muoz, \& Rodrguez-Carvajal, 2011), whereas job resources, which refer to those factors that can help reduce job demands and are beneficial for achieving work goals or increasing one's commitment, contribute to the development of a positive organizational climate (Salanova, Del Lbano, 2018)

From the two variables, professional commitment and organizational climate, in its singular capacity, organizational climate best influences the work engagement having the highest beta coefficient. However, professional commitment can also influence work engagement but with the support of other variables. This implies that professional commitment and maintaining a positive organizational climate manifest their work engagement. With this, non-teaching personnel can excellently perform their duties if they are highly engaged in their work.

This means that work engagement can influence how employees demonstrate their professional commitment and adherence to a positive company atmosphere. This supports Deci and Ryan's (1985) Self-Determination Theory, which examines factors affecting employee motivation. This idea was established and used in professional and academic studies on employee engagement. Employee engagement and human behavior have been linked to Self-Determination Theory. The degree to which an employee is engaged is determined by their ability to control personal actions and goals. Employee behaviors include one's commitment to and behavior in their environment and maintaining a positive organizational climate.

\section{Conclusion}

Professional commitment is extremely high, as evidenced by respondents' high ratings for all of its markers, including affective professional commitment, continuation professional commitment, and normative professional commitment. On the other hand, the organizational climate is really positive in general. Its indicators indicate that all of its indicators performed exceptionally well. The overall degree of work engagement among non-teaching professionals is quite high, as are all its indicators, including cognitive work engagement, emotional work engagement, and physical work engagement.

Additionally, substantial connections existed between professional dedication and job engagement and between the organizational atmosphere and job engagement. The findings corroborate Bakker and Demerouti's (2008) job demands resources model (JD-R model), which postulates that work engagement results from the intrinsically motivating nature of resources. Two available resources are differentiated: job resources, which are associated with organizational climate, and personal resources, which are defined as aspects of the self-associated with resiliency and refer to the capacity to effectively control and influence one's environment.

In its singular capacity, among professional commitment and organizational climate, organizational climate best influences the work engagement having the highest beta coefficient. However, professional commitment can also influence teaching competence but with the support of other variables. This validates the employee engagement theory of Hellivig (2017), which emphasized that if members in an organization are fully engaged, goals can be achieved easily. In order to have an engaging workplace, members must be fully committed, and a positive organizational climate must be maintained. He also emphasized that being engaged simply means being committed, motivated, and enjoying a good organizational climate.

\section{Recommendations}

The study revealed a very high level of professional commitment and a very high-level organizational climate. However, professional commitment and organizational climate are very high. There is still a need for non-teaching personnel to continue enhancing their engagement to perform their tasks excellently and achieve higher work performance. Further, the item-statements being disrupted in changing profession and feeling guilty and not right to leave the profession have the lowest rating though high, which could mean that non-teaching personnel need to focus on enhancing their professional duties and responsibilities. This can be done through re-induction orientation.

Meanwhile, it was identified that in the level of organizational climate, item-statements: supervisors are not being afraid to discuss their feelings with their subordinates, supervisors are treating the mistakes of 
subordinates with understanding and helping them to learn and not being hesitant to discuss our problems with our supervisors are the lowest which implied the need for non-teaching personnel to engage their selves among others to collaboratively improve their engagement. The provision of capacity-building training can best address the problem, for this may allow them to mingle with others on how to improve their work and build affective involvement with others.

The level of work engagement is very high. But, physical work engagement is being identified as the lowest, though still high, which needs concern and attention. Non-teaching personnel may be encouraged to undergo professional development through training related to their tasks to be fully oriented and be aware of maximizing their potentials on the fulfillment of their work duties and responsibilities.

Additionally, the study found a significant relationship between professional commitment and work engagement and organizational climate and work engagement; thus, the researcher recommends that nonteaching personnel continuously enhance professional commitment and maintain the organizational climate for them to have a strong work engagement. It is recommended that non-teaching personnel continue to maintain and find innovative ways to intensify their work engagement to maintain good relations among others, implement working practices properly, and perform well in their tasks, which can be manifested in their engagement.

The result underscores in its singular capacity that organizational climate best influences the work engagement having the highest beta coefficient. Therefore, the researcher recommends that the Department of Education formulate programs that may further provide relevant information in strengthening work engagement, which will guide non-teaching personnel to improve their work performance.

Subsequently, albeit the research finding shows a significant influence of professional commitment and organizational climate on work engagement, the researcher still recommends that further research regarding the other factors associated with work engagement may be conducted. Further studies may be done to validate the results of the present study.

Additionally, the study found a significant relationship between professional commitment and work engagement and organizational climate and work engagement. Thus, the researcher recommends that nonteaching personnel continuously enhance professional commitment and maintain the organizational climate for them to have a strong work engagement. It is recommended that non-teaching personnel continue to maintain and find innovative ways to intensify their work engagement to maintain good relations among others, implement working practices properly, and perform well in their tasks, which can be manifested in their engagement.

The result underscores in its singular capacity that organizational climate best influences the work engagement having the highest beta coefficient. Therefore, the researcher recommends that the Department of Education formulate programs that may further provide relevant information in strengthening work engagement, which will guide non-teaching personnel to improve their work performance.

Subsequently, albeit the research finding shows a significant influence of professional commitment and organizational climate on work engagement, the researcher still recommends that further research regarding the other factors associated with work engagement may be conducted. Further studies may be done to validate the results of the present study.

\section{References}

1. Albrecht, S. L. (2015). Handbook of employee engagement: perspectives, issues, research and practice. Northampton: Edward Elgar Publishing.

2. Ayaz-Yilmaz, K. (2016). An empirical assessment of organizational commitment and organizational effectiveness. Administrative Science Quarterly, 26, 1-13.

3. Bagraim, M. (2003). Organizational Commitment of Teachers in Educational Organizations. Journal of Education and Journal of Education and Training Studies, 22(108), 56-62

4. Baier, M. (2016) Innovation is not enough. Journal of Organizational Behavior, 24, 45-68. Retrieved from https://doi.org/10.1002/job.179.

5. Bakker, A.B. \& Albrecht, S. L. 2018 Work engagement: current trends. Career Development International Journal. Retrieved from https://www.emerald.com/insight/content/doi/10.1108/CDI11-2017-0207/full/html

6. Bakker, A. B. (2009). Daily fluctuations in work engagement: an overview and current directions. European Psychologist Journal, Vol. 19 No. 4, pp. 227-236. 
7. Bakker, A. B. \& Demerouti, E. (2008). Potential problems in statistical control of variables in organizational research. Organizational Research Methods, 8, 274-289. Retrieved on October 18, 2019 from https://doi.org/10.1177/10944 28105278021.

8. Bakker, A. B., \& Demerouti, E. (2017). Job Demands-Resources Theory. In Wellbeing. John Wiley \& Sons, Ltd. Retrieved from http://onlinelibrary.wiley.com/doi/10.1002/9781118539415.wbwell019/abstract

9. Bakker, A. B., Hakanen, J. J., Demerouti, E., \& Xanthopoulou, D. (2014). Job resources boost work engagement, particularly when job demands are high. Journal of Educational Psychology, 99(2), 274-284. http://doi.org/10.1037/0022-0663.99.2.274

10. Bandura, A. (1989). Social cognitive theory. In R. Vasta (Ed.). Annals of child development. Vol.6. Six theories of child development (pp. 1-60). Greenwich, CT: JAI Press.

11. Bayram, M. \& Aypay, P. (2017). The Management Commitment to OHS, Employee Satisfaction and Safety Performance: An Empirical Study. International Journal of Latest Engineering and Management Research (IJLEMR). Volume 03 - Issue 07, 63-71.

12. Bentler, E., Yuan, H., \& Eu, R. (2010). Sustainable development through commitment to organizational change: The implications of organizational culture and individual readiness for change. Journal of Workplace Learn. 2020, 33, 180-196.

13. Bhandari, M. (2021). The mediating role of nurses' professional commitment in the relationship between core self-evaluation and job satisfaction. International Journal of Occupational Environment and Health; 31(5): 649-658.

14. Boyd, D. (2016). The influence of school administrators on teacher retention decisions. Retrieved on October 23, 2019 from https://doi.org/10.3102/0002831210380788

15. Bryson, A. \& White, L. (2017). Wellbeing and Commitment among Staff in Schools and Elsewhere. Institute of Labor Economics. Retrieved on October 14, 2019 from http://ftp.iza.org/dp11456.pdf.

16. Bestieler, L. (2016). Trust Formation in Collaborative New Product Development. Journal of Product Innovation Management, 23: 56-72.

17. Caniels, M. \& Baaten, S. (2018) How a Learning-Oriented Organizational Climate is Linked to Different Proactive Behaviors: The Role of Employee Resilience. Social Indicators Research Journal 143(3). Retrieved from https://www.researchgate.net/publication/327487234_How_a_LearningOriented_Organizational_Cli mate_is_Linked_to_Different_Proactive_Behaviors_The_Role_of_Employee_Resilience

18. Cardwell, M.E. (2016). Patterns of relationships between teacher engagement and student engagement. Education Doctoral. Paper. Research in Higher Education, 39, 65-86.

19. Castro, M. \& Martins, N. (2010). The relationship between organizational climate and employee satisfaction in a South African information and technology organization. SA Journal of Industrial Psychology, 36(1), 800-809.

20. Changing Minds (2017). Leadership and commitment. Retrieved from https://changingminds.org/disciplines/leadership-commitment/leadership.htm

21. Chaudhary, R., Rangnekar, S., \& Barua, M. K. (2018). HRD Climate, Occupational SelfEfficacy and Work Engagement: A Study from India. The Psychologist-Manager Journal, 15(2), 86-105. http://doi.org/10.1080/10887156.2012.676938

22. Chaudhary, R., Rangnekar, S., \& Barua, M.K. (2017). HRD Climate, Occupational Self-Efficacy and Work Engagement: A Study from India. The Psychologist-Manager Journal, 15(2), 86-105.

23. Chuang, L. (2016). Service-Oriented High-Performance Work Practices as Predictors of Retail Employees' Work Engagement and Service Climate Perceptions. Services Marketing Journal. Retrieved from https://www.tandfonline.com/doi/full/10.1080/15332969.2020.1830638

24. Ciplinski, C. (2018). Organizational commitment and teachers in education. Ankara: An1 Publishing.

25. Cleary, T. J. \& Zimmerman, B. J. (2017). Adolescents' Development of Personal Agency. The Role of Self-Efficacy Beliefs and Self-Regulatory Skills. In F. Pajares, \& T. Urdan (Eds.), Self-Efficacy Beliefs of Adolescents, 7(45-69). Greenwich: Information Age.

26. Cooper-Hakim, A. and Viswesvaran, C. (2005). The Construct of Work Commitment: Testing an Integrative Framework. Psychological Bulletin, 131, 241-259. Retrieved from https://doi.org/10.1037/0033-2909.131.2.241 
27. Costa, A. C. (2016). Work team trust and effectiveness. Personnel Review, Journal, 32(5), 605-622. https://doi.org/10.1108/00483480310488360

28. Crossman, P. (2018).Meaningfulness, professional commitment, and work engagement: The intersection of a deeper level of intrinsic motivation. Advances in Developing Human Resources, 11, 189-203. doi:10.1177/152342309333147

29. Dawson, J. F., Gonzalez - Roma, V., Davis, A. \& West, M. A. (2019). Organizational climate and climate strength in UK Hospitals. European Journal of work and organizational psychology, 17(1), $89-111$.

30. Deci, E. L., \& Ryan, R. M. (1985). Intrinsic motivation and self-determination in human behavior. New York: Plenum.

31. Demerouti, E., Bakker, A. B., Nachreiner, F., Schaufeli, W. B. (2015). The job demands resources model of burnout. Journal of Applied Psychology, 86(3), 499-512. http://doi.org/10.1037/00219010.86.3.499

32. Demerouti, E., Mostert, L., \& Bakker, A. B. (2015). Burnout and work engagement among teachers. Journal of School Psychology, 43(6), 495-513

33. Demircan, L. \& Ceylan, P. (2003) Organizational commitment of teachers in urban schools: Examining the effects of team structures. Urban Education, 41, 603-627.

34. Engelberg-Moston, R. (2019) Perceived organizational support and employee diligence, commitment, and innovation. Journal of Applied Psychology, 75, 51-59.

35. Febriansyah, H., Pringgabayu, D., Hidayanti, N., Febriante, F. (2018). Enhancing the employee engagement through the organizational climate (a study of school of business and management). Journal of Business and Retail Management Research (JBRMR), Volume 12 Issue 3, DOI: https://doi.org/10.24052/JBRMR/V12IS03/ART-09

36. Fredricks, J. A. (2017) A study of relationship between job satisfaction and organizational commitment among restaurant employees. Retrieved from http://hotel.unlv.edu/ pdf/jobSatisfaction.pd $\mathrm{f}$

37. Fredricks, J. A., Blumenfeld, P. C., \& Paris, A. H. (2017). School engagement: Potential of the concept, state of the evidence. Review of Educational Research Journal, 74(1), 59-109. doi:10.3102/00346543074001059

38. Fresko, P., Kfir, P., \& Nasser, L. (2016). The role of positive emotions in positive psychology: The broaden-and-build theory of positive emotions. American psychologist, 56(3), 218.

39. Funtowicz, R. (2018). Perceived Organizational Support. Journal of Applied Psychology, 71(31).

40. Garrosa, L., Moreno-Jimenez, P., Rodriguez- Munoz, P., Rodriguez-Carvajal, K. (2011) Principles, fundamentals and theories of organizational climate. Esfahan publication of SID unit.

41. Gill, P. \& Kaur, R. (2017). Manual of professional commitment scale for employees. National Psychological Corporation: Agra.

42. Grandey A. A. (2000). Emotional regulation in the workplace: a new way to conceptualize emotional labor. Journal in Occupational Health Psychology 5 95-110. 10.1037/1076-8998.5.1.95

43. Grimsly, M.A. (2018). Specifying organizational contexts: Systematic links between contexts and processes in organizational behavior. Journal of Organizational Behavior, 28(7), 859-863.

44. Gulzar, G. (2018). A Study of the Correlates of Organizational Commitment Among Secondary School Teachers. Journal of Issues and Ideas in Education (IIE), Vol. 1. Pp. 12-15.

45. Hair, R., Anderson, O., Tatham, N., \& Black, L. (2014). Efficacy Beliefs, Job Satisfaction, Stress and Their Influence on the Occupational Commitment of English-Medium Content Teachers in the $\begin{array}{lllll}\text { Dominican } & \text { Republic. } & \text { Educational } & \text { Psychology, } & 34,\end{array}$ http://dx.doi.org/10.1080/01443410.2013.814193

46. Haugsnes, L. (2016) Career commitment: reexamination and an extension. Journal of Vocational Behavior, 61, 73-91. https://doi.org/10.1006/jvbe.2001.1844

47. Hellevig, J. (2017). The Theory of Employee Engagement. Retrieved from https://www.awaragroup.com/blog/the-theory-of-employee-engagement/

48. Ibrahim, K. (2015). Secondary school climate: A revision of the OCDQ. Educational Administration Quarterly, 23, 31-48. 
49. Kirkpatrick, C. L. (2017). To invest, coast or idle: Second-state teachers enact their job engagement. Paper presented at the American Educational Research Association annual conference, Chicago, IL.

50. Korczynski, M. (2016). Investigating the organizational trust perceptions of primary and secondary school teacher in terms of certain variables. Unpublished Master Thesis, Ahi Evran University Social Sciences Institute, Kirşehir.

51. Kose, J. (2016). The relation between school leadership from a distributed perspective and teachers' organizational commitment: Examining the source of the leadership function. Educational Administration Quarterly, 47(5), 728-771. Jha

52. Kramer, M. R. (2009). Trust and distrust in organizations: emerging perspectives, enduring $\begin{array}{lllll}\text { questions. } & \text { Annual } & \text { Review }\end{array}$ https://doi.org/10.1146/annurev.psych.50.1.569

53. Kumar, R. \& Sia, S. (2017). Employee Engagement: Explicating the Contribution of Work Environment. Retrieved on October 28, 2019 from https://doi.org/10.1177/0258042X1103700104

54. Kuok, A. \& Taomina, R. (2017) Work Engagement: Evolution of the Concept and a New Inventory. Psychological Thought, Vol. 10(2), 262-287, doi:10.5964/psyct.v10i2.236

55. Labaree, R. (2017). Qualitative research: A Guide to design and implementation. San Francisco, CA: Jossey-Bass.

56. Laerd Dissertation (2018). Total population sampling. Retrieved from https://dissertation.laerd.com/total-population-sampling.php

57. Lisbona, A. 2018). The effects of work engagement and self-efficacy on personal initiative and performance. Psicothema, Vol. 30, No. 1. Retrieved from https://www.redalyc.org/ articulo.oa?id=72754594014

58. Lockwood, N.R. (2017). Leveraging employee engagement for competitive advantage: HR's strategic role (SHRM Research Quarterly Report). Alexandria, VA: Society for Human Resource Management.

59. Luke, R. \& Luke, M. (2018) Human organizations: Its management and values. New York: McGraw-Hill

60. Macey, W. H. \& Schneider, B. (2015). The meaning of employee engagement. Industrial and Organizational Psychology, 1 (2008), 3-30.

61. MacTavish \& Kolb (2016). Experiential learning theory and engagement. Retrieved from https://www.researchgate.net/figure/Kolbs-experiential-learning-cycle-Kolbs-2016-model-oflearning-includes-opposing_fig14_331232714

62. Maheshwari, M. N. (2007) . The relationships of emotional intelligence, leadership behavior and organizational commitment on organizational readiness for change in a higher learning institution. Doctorate dissertation. Universiti Putra Malaysia.

63. Mansell, M. (2019). The impact of organizational culture on organizational commitment. University of South Africa: Pretoria.

64. McLeod, D. \& MacDonell, N. (2016). Engaging for success. Enhancing performance through employee engagement. London: Department for Business, Innovation and Skills.

65. Mercurio, Z. (2017). Affective commitment as a core essence of organizational commitment: An integrative literature review. Retrieved from https://doi.org/10.1177/1534484315603612

66. Meyer, J. P., \& Allen, N. J. (2016). Commitment in the workplace: theory, research, and application. Thousand Oaks, CA: Sage Publications.

67. Mowday, P. (2017). Unit performance situational factors and employee attitudes in spatially separated work units. Organizational Behavior and Human Performance, 12, 231-248.

68. Nazari, K., \& Emami, M. (2017). Antecedents and consequences of organizational commitment. Interdisciplinary Journal of Contemporary Research in Business, 3(9), 484-493.

69. Nurharani S., Samsu, N. Z. \& Kamalu, N. M. (2018). The impact of organizational climate on teachers' job performance. Educational Research e-Journal, 2 (1), 71-82.

70. Ozer, N. (2006). High school teachers' perception of organizational trust. Journal of Ege Egitim, $7(1), 103-124$

71. Patel, A. (2017). Employee Engagement for an Increasingly Educated Workforce: The Impact of Competitive Team Climate. Journal of Personnel Psychology 16(4):186-194, DOI:10.1027/1866$5888 / \mathrm{a} 000188$ 
72. Putter, L. (2010). The relation between organizational climate and performance and an investigation of the antecedents of organizational climate. (Master's Thesis). Delft Technology University, Delft.

73. Raja, H. (2019). Influence of Organizational Climate on Performance in Manufacturing Industry. Suraj Punj Journal For Multidisciplinary Research, 9( 3), 147-157.

74. Relo, P. W. (2016). The relationship among psychological empowerment, job satisfaction and organizational commitment of staff members at the University of Namibia. Master's dissertation. The University of Namibia

75. Richards, B.L. (2017). Job engagement: Antecedents and effects on job performance. Academy of Management Journal, 53, 617-35.

76. Salanova M., Agut S., Peiro J. M. (2015). Linking organizational resources and work engagement to employee performance and customer loyalty: the mediation of service climate. Journal of Applied Psychology, 90 1217-1227. 10.1037/0021-9010.90.6.1217

77. Salanova, M., Del Líbano, M., Llorens, S., \& Schaufeli, W. B. (2018). Engaged, Workaholic, Burned-Out or Just 9-to-5? Toward a Typology of Employee Well-being. Stress and Health Journal, http://doi.org/10.1002/smi.2499

78. Sancak, R. L. (2016). The influence of ethical fit on employee satisfaction, commitment and turnover. Journal of Business Ethics, 13, 939-948.

79. Schaufeli, W., Salanova, M., Roma, P., \& Bakker, A. (2017). A cross-national study of work engagement as a mediator between job resources and proactive behavior. The International Journal of Human Resource Management, 19, 116-31

80. Schaufeli, W. B., Taris, T. W., \& Van Rhenen, W. (2018). Workaholism, burnout and engagement: Three of a kind or three different kinds of employee well-being. Applied Psychology: an International Review, 57(2), 173-203. Retrieved from https://doi.org/10.1111/j.14640597.2007.00285.x

81. Schaufeli, W. B. \& Bakker, A. B. (2015). The role of personal resources in the job demandsresources model. International Journal of Stress Management, 14(2), 121-141. http://doi.org/10.1037/1072-5245.14.2.121

82. Schaufeli, W. B. \& Salanova, M. (2017). Linking organizational facilitators and work engagement to extra-role performance and customer loyalty: theme diating role of service climate. Journal of Applied Psychology, 2005, 90(6), 1217-1227.

83. Schein, K. (2017). Influence of psychological empowerment on affective, normative and continuance commitment: A study in the Indian IT industry. Journal of Indian Business Research, 3(4), 263-282.

84. Scheneider, (2016). Organizational Climate and Culture, Annual Review of Psychology, 64(1), 36188.

85. Schneiderman, M. (1999). Predictors of work engagement among teachers in Regina and Saskatoon. Doctoral dissertation. Faculty of Graduate Studies and Research, University of Regina.

86. Selden, P. and Sowa, M. (2016). Organizational climate. In: Nesselroade J.R., Cattell R.B. (eds) Handbook of Multivariate Experimental Psychology. Perspectives on Individual Differences. Springer, Boston, MA

87. Smith. M. \& Marwick, W. (2014). Employee involvement climate, task and citizenship performance, and instability as a moderator. International Journal of Human Resource Management, 42(4), 1-22. doi/abs/10.1080/09585192.2016.1184175

88. Smith, M. (2019). Ethical Climate and Employee Turnover Intention in the Ready-Made Garment Industry. Global Business and Organizational Excellence Journal, 36(2), 61-73. doi.org/10.1002/joe. 21770

89. Solinger, O.N. (2008). Beyond the three-component model of organizational commitment. Journal of Applied Psychology, 93, 70-83.

90. Sonnentag, P. (2017). Recovery, work engagement, and proactive behavior: a new look at the interface between non-work and work. Journal of Applied Psychology, 88, 518-528. https://doi.org/10.1037/0021-9010.88.3.518

91. Swann, G. (2016). Organizational Commitment: Definition, Theory \& Types. Retrieved on October 28, 2019 from https://study.com/academy/lesson/organizational-commitment-definition-theorytypes.html. 
92. Towler, P. 2020). Working today: Understanding what drives employee engagement. Stamford. The Towers Perrin.

93. Turner, R. \& Muller, J.R. (2016). Communication and cooperation on projects between the project owner as principal and the project manager as agent. European Management Journal, 21(3), 327336.

94. Tümkaya, S., \& Uştu, H. (2016). A research on primary school teachers: the relationship between exhaustion and occupational commitment. Journal of Mersin University Education Faculty, 12(1).

95. Uysal, H. T. (2018). Effect of organizational climate on the development of professional commitment of interns. Business and Economics Research Journal, 4 (3), 93-110.

96. Van der Werf, R. (2020). Keys to organizational commitment. Retrieved from https://www.effectory.com/knowledge/3-key-types-of-organisational-committment/

97. Walton, R. (2017). Quality of work life activities: A research agenda. Professional Psychology, 11(3), 484-493. https://doi.org/10.1037/0735-7028.11.3.484

98. Wang, C. \& Saunders, M. (2018). Affective and continuance commitment in public private partnership. Journal on Employee Relations 32(4):396-417. DOI:101108/01425451011051613

99. Ware, H. \& Kitsantas, A. (2016). Teacher and collective efficacy beliefs as predictors of professional commitment. The Journal of Educational Research, 100(5), 303-310.

100. Williams, J. (2018). Job satisfaction and organizational commitment. Retrieved from the Sloan Work and Family Research Network website: http://wfnetwork.bc.edu/encyclopedia_entry.php?id=244\&area=academics

101. Wolter, C. \& Taylor, J. (2012). The job demands-resources model: A meta-analytic review of longitudinal studies. Work \& Stress Journal, 33:1, 76-103, DOI:10.1080/02678373.2018.1529065

102. Wong, C.S. (2018). The effects of leader and follower emotional intelligence on performance and attitude: An exploratory study. Leadership Perspectives Journal. Routledge, 97-128.

103. Yildiz, K. (2013). Teachers' organizational trust and organizational fair perceptions. Journal of AIB University Social Sciences Institute, 2013, 13(1), 289-316

104. Yilmaz, K. (2016). The Teachers' organizational awareness and organizational trust perceptions and level organizational effectiveness of schools. Unpublished Master Thesis, Adnan Menderes University Social Sciences Institute: Aydın.

105. Zidane, J.T. (2016). Categorization of organizational factors and their impact on project performance. Procedia - Social and Behavioral Sciences, 226 (2016) 162 - 169. 